\title{
Wykorzystanie emisji akustycznej do monitorowania rozwoju pęknięć w konstrukcjach betonowych
}

\section{Monitoring of crack propagation in concrete structures using the acoustic emission method}

\section{Streszczenie}

Badania laboratoryjne nad zastosowaniem technik nieniszczących do oceny stanu technicznego konstrukcji pracujących w warunkach dużych obciążeń eksploatacyjnych pozwalają istotnie poszerzyć wiedzę o mechanizmach zniszczenia. Szczególną rolę odgrywa w tym aspekcie metoda emisji akustycznej (AT). Artykuł pokazuje możliwości zastosowania tej metody do monitorowania istniejących i rozwijających się mikropęknięć w konstrukcjach betonowych, co stwarza możliwość detekcji powstającego zagrożenia i pozwala uchronić obiekt przed zniszczeniem.

Badania w statycznej próbie ściskania rdzeni betonowych z równoczesną rejestracją sygnałów akustycznych pozwoliły określić charakterystyczne parametry sygnałów generowanych przez tarcie oraz tworzenie się oraz rozwój mikropęknięć. Analiza zmian intensywności i aktywności emisji akustycznej umożliwiła wykrycie momentu, w którym istniejące $\mathrm{w}$ materiale mikropęknięcia propagują $\mathrm{w}$ materiale i doprowadzają do całkowitego zniszczenia konstrukcji. Zebrana w ten sposób charakterystyka akustyczna pozwoli skutecznie monitorować rozwój mikropęknięć podczas badań konstrukcji betonowych.

\section{Abstract}

Laboratory research using non-destructive techniques for assessment of structures working under heavy operating loads, significantly extends knowledge about the failure mechanisms. A special role in this aspect plays the acoustic emission method (AT). The article shows the possibilities of this method to monitoring of existing and propagating micro-cracks in concrete structures. It allows to detect emerging risk and to protect object from damage.

Static compression tests with simultaneous recording of acoustic signals generated in the material helped to determine the characteristic parameters of the signals generated by friction and the formation and propagation of micro-cracks. Analysis of acoustic emission intensity and activity allowed to detect the point at which the existing micro-cracks propagation in the material and lead to destruction of the structure. Identification of the characteristics of acoustic emission signals allows effective monitoring of concrete constructions in service conditions.

\section{Wstęp}

Badania nad zastosowaniem technik nieniszczących do oceny stanu technicznego urządzeń i konstrukcji pracujących w warunkach dużych obciążeń

Mgr inż. Radosław Karczewski, dr inż. Tomasz Lusa, dr inż. Andrzej Zagórski - Politechnika Warszawska, prof. dr hab. inż. Rafał Wiśniowski - Akademia Górniczo-Hutnicza w Krakowie. eksploatacyjnych są od wielu lat prowadzone i rozwijane na Wydziale Inżynierii Materiałowej Politechniki Warszawskiej. Szczególną rolę odgrywa pod tym względem metoda emisji akustycznej, pozwalająca oceniać stan techniczny konstrukcji w sposób globalny, zarówno podczas obciążenia pojedynczego, jak i długookresowego monitoringu obiektu pracującego pod obciążeniem.

Terminem emisja akustyczna (AE) określa się chwilowe fale sprężyste wywołane przez gwałtowne wyzwolenie energii zgromadzonej w materiale [1]. Fale te 
generowane są w miejscach nazywanych źródłami $A E$ i są zwykle efektem wielu nakładających się na siebie zjawisk. W wyniku przyłożonego bodźca zewnętrznego (np. naprężenia, ciśnienia, gradientu temperatury, pola magnetycznego itp.) fale sprężyste propagują ze źródła do powierzchni ograniczającej materiał, gdzie mogą być rejestrowane przez odpowiednie przetworniki odbiorcze.

W materiałach kompozytowych, za jakie niewątpliwie należy uznać betony nasączone żywicą poliuretanową, podstawowym źródłem emisji akustycznej jest powstawanie i rozwój mikropęknięć. Pod wpływem obciążenia mikropęknięcia moga ulegać propagacji, wskutek czemu stają się aktywnymi źródłami AE. Ich wielkość i miejsce występowania są ważnymi czynnikami przy analizie zagrożenia dla integralności konstrukcji, ponieważ niestabilne wady zwykle propagują na długo przed jej zniszczeniem. W ten sposób rozwijające się nieciągłości stają się aktywnymi źródłami $A E$, stwarzając możliwość detekcji powstającego zagrożenia.

\section{Metodyka badań}

\section{Badany materiał}

Badaniu metodą AT poddano wycinki z konstrukcji fundamentowej zbiornika magazynującego produkty petrochemiczne. Konstrukcja ta składała się z płyty żelbetowej oraz słupów typu „Franki”, na których była oparta. Szczególną uwagę skupiono na płycie żelbetowej, która została oddana po naprawie do eksploatacji.

Płyta fundamentowa została wykonana $\mathrm{z}$ betonu żwirowego o $\mathrm{R}_{\mathrm{w}}=170 \mathrm{kG} / \mathrm{cm}^{2}$, odpowiadającemu w przybliżeniu klasie betonu B15, zbrojonego stalą zbrojeniową gładką i zabezpieczonego betonem natryskowym. W wyniku wieloletniej eksploatacji konstrukcji oraz działania dużych gradientów temperatur materiał płyty uległ degradacji. Na jej powierzchni pojawiły się zarysowania oraz liczne wykwity węglanowe.

$\mathrm{Na}$ skutek pogorszenia parametrów wytrzymałościowych betonu podjęto środki, które miały polepszyć właściwości płyty nośnej i zapobiec dalszej degradacji betonu. Wykonano w tym celu pod dużym ciśnieniem iniekcję żywicami epoksydowymi i poliuretanowymi do materiału płyty wypełniającymi pustki i pęknięcia.

Po zakończeniu procesu wstrzykiwania z całej konstrukcji płyty fundamentowej zostały pobrane próbki do badań laboratoryjnych, mających określić głębokość penetracji żywic oraz wyznaczyć podstawowe parametry wytrzymałościowe w próbie jednoosiowego ściskania. Próbki w formie rdzeni o średnicy $100 \mathrm{~mm}$ i wysokości $200 \mathrm{~mm}$ pobrano metodą odwiertową. Próbki poddano statycznej próbie ściskania z jednoczesnymi pomiarami emisji akustycznej, czego celem było wyznaczenie charakterystyki akustycznej generowanych sygnałów oraz ich częstotliwości.

\section{Metodyka badań laboratoryjnych}

Pomiary $A E$ w jednoosiowej statycznej próby ściskania zostały przeprowadzone na stanowisku badawczym składającym się z aparatury pomiarowej AE oraz maszyny wytrzymałościowej. W skład aparatury pomiarowej wchodziły: system pomiarowy AMSY-5: M6-2 firmy Vallen z sześcioma kartami pomiarowymi ASIP-2 do rejestracji i przetwarzania sygnału $A E$; czujniki: VS30-SIC-46dB, VS45-H i AE1045S o zakresach częstotliwości odpowiednio $20 \div 80,20 \div 450$ i $100 \div 1500 \mathrm{kHz}$. Czujniki zamontowano bezpośrednio na powierzchni bocznej walcowego rdzenia.

W pomiarach została użyta statyczna maszyna wytrzymałościowa Walter + Bai ag, z płaskimi stolikami do ściskania próbek walcowych. Pomiędzy próbką a stemplami maszyny wytrzymałościowej umieszczono przekładki gumowe eliminujące zakłócenia wynikające z tarcia powierzchni o siebie. Schemat stanowiska badawczego pokazano na rysunku 1.

Pomiar AT prowadzono do osiągnięcia dezintegracji próbki betonowej. Rejestrację sygnałów AE prowadzono przez cały czas poddawania próbki naprężeniom. Obciążanie próbek realizowano zgodnie ze schematem pokazanym na rysunku 2 [2].

Celem badań AT było scharakteryzowanie sygnałów akustycznych, generowanych przez różnego typu uszkodzenia, podczas odkształcania materiału. W tym celu analizie i porównaniu poddano wiele

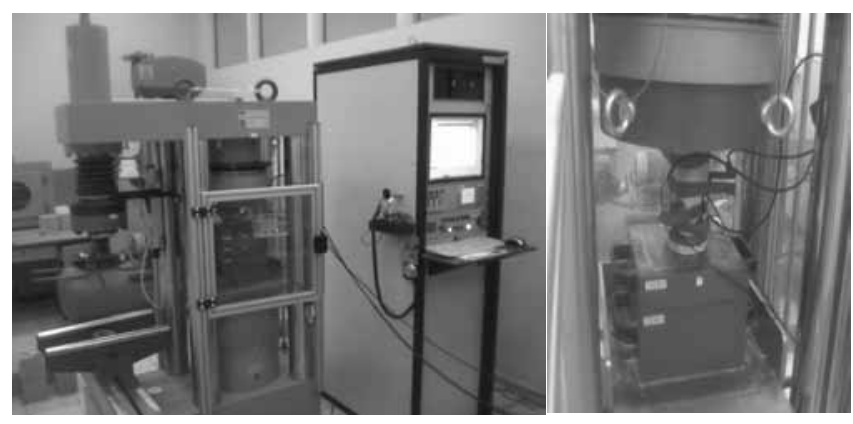

Rys. 1. Stanowisko badawcze do pomiarów AE podczas statycznej próby ściskania

Fig. 1. AE tests bench for static compression test

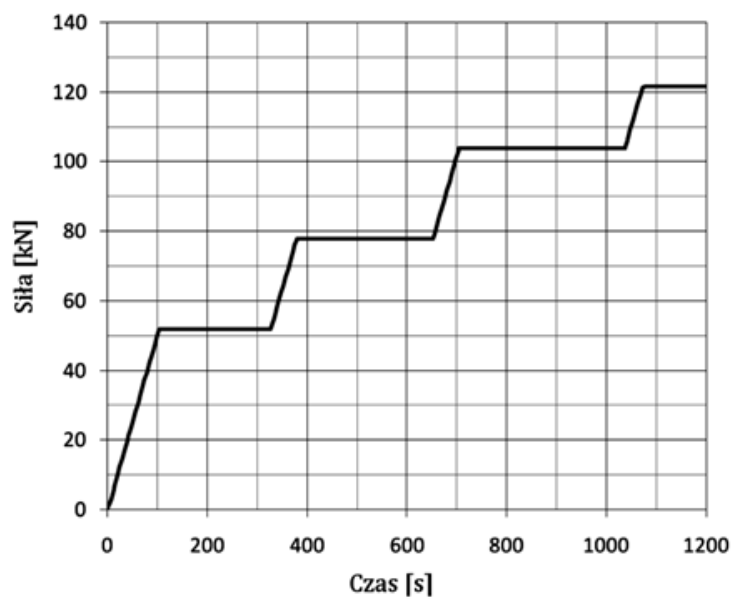

Rys. 2. Schemat obciążania próbek podczas badania [2]

Fig. 2. Stress sequence [2] 
parametrów, takich jak: amplituda, częstotliwość sygnałów, liczba zliczeń, energia skumulowana, RMS, czas trwania sygnałów, tempo zliczeń. Parametry te odnoszono zarówno do przyłożonych naprężeń, jak i czasu. Stworzone wykresy obrazujące zmiany wartości wybranych parametrów przedstawiono na rysunkach $3 \div 10$.

\section{Wyniki badań laboratoryjnych}

W początkowej fazie próby ściskania rdzeni betonowych zaobserwowano nieznaczną aktywność emisji akustycznej podczas wzrostu obciążenia. Podczas dwóch pierwszych wytrzymań, przy stałej sile 52 i 78 $\mathrm{kN}$, nie zarejestrowano wzrostu tempa zliczeń (count rate) rejestrowanych sygnałów emisji akustycznej (rys. 3). Znaczny wzrost tempa zliczeń nastąpił podczas podnoszenia obciążenia do $104 \mathrm{kN}$ oraz wytrzymania przy tej sile (rys. 4). Świadczy to o istnieniu w strukturze materiału uszkodzeń, których rozwój przy tym stanie naprężenia przebiega w sposób niekontrolowany. Uszkodzenia te przejawiają tendencję do dalszego rozwoju. Ich rozwój tych uszkodzeń w trakcie kolejnego podnoszenia obciążenia doprowadził do zniszczenia betonowego rdzenia.

Proces niszczenia badanego rdzenia betonowego przechodził więc w trzech etapach (rys. 4) [3]. W pierwszym etapie (obciążenie do $78 \mathrm{kN}$ ) dochodziło do stabilnej inicjacji mikropęknięć, które powstały na skutek istnienia $w$ betonie wad powstałych na etapie produkcji (pory, szczeliny) oraz w czasie eksploatacji (korozja betonu). W kolejnych etapach (podnoszenie obciążenia od 78 kN i wytrzymanie na poziomie 104 kN) zachodził znaczny rozwój mikropęknięć oraz powstawały nowe mikropęknięcia. Ten proces zaobserwowano zwłaszcza podczas wytrzymania na poziomie 104 kN, gdy wzrasta aktywność i intensywność akustyczna widoczna jako przyrost liczby sygnałów AE oraz wzrost

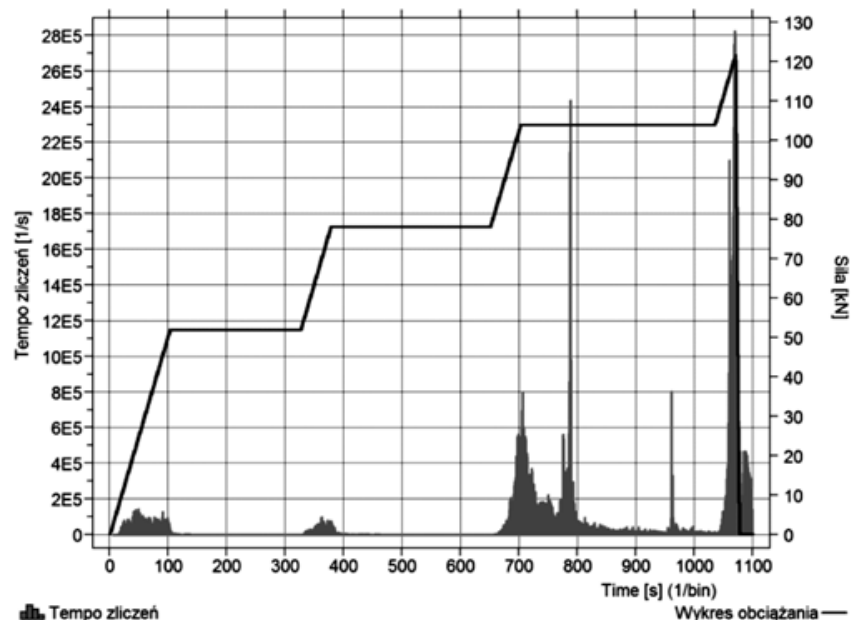

Rys. 3. Tempo zliczeń sygnałów AE w funkcji czasu pomiaru dla poszczególnych wytrzymań

Fig. 3. Count rate in relation to hold periods as a function of time ich amplitudy. W ostatnim, trzecim etapie podnoszenia obciążenia, istniejące $\mathrm{w}$ materiale mikropęknięcia propagują w materiale i doprowadzają do całkowitego zniszczenia próbki.

W dalszej analizie skupiono się na porównaniu parametrów sygnałów rejestrowanych podczas ostatniego wytrzymania, podnoszeniu siły do uzyskania maksymalnej wytrzymałości na ściskanie oraz momentu, w którym próbka uległa dekohezji. Wyznaczono charakterystyczne dla procesu zniszczenia parametry sygnałów akustycznych, takie jak częstotliwość, czas narastania, czas trwania, liczba zliczeń, amplituda i energia.

W tym celu wyznaczono trzy charakterystyczne obszary: A-1, A-2 i A-3, pokazane na rysunku 5.

Sygnały z wytypowanych obszarów zobrazowano na wykresie przedstawiającym energię w funkcji liczby zliczeń sygnałów AE powyżej progu dyskryminacji (rys. 6 ). Do dalszej analizy wytypowano sygnały o energii większej niż 500 eu., różniące się wartościami zliczeń powyżej progu dyskryminacji, co pozwoliło scharakteryzować procesy i towarzyszącą im emisje akustyczną.

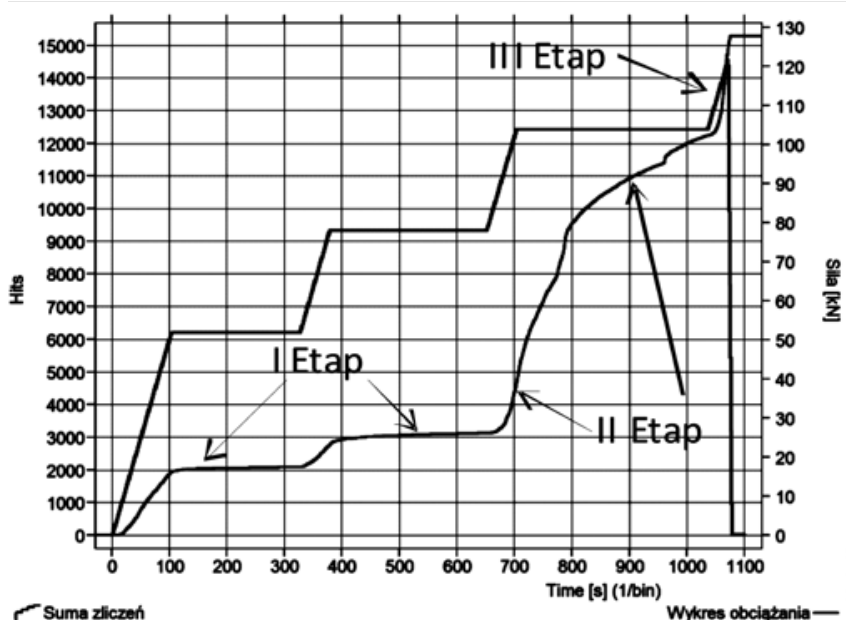

Rys. 4. Sumaryczna liczba zarejestrowanych sygnałów AE oraz obciążenie próbki w funkcji czasu badania

Fig. 4. Summary number of hits and load as a function of time

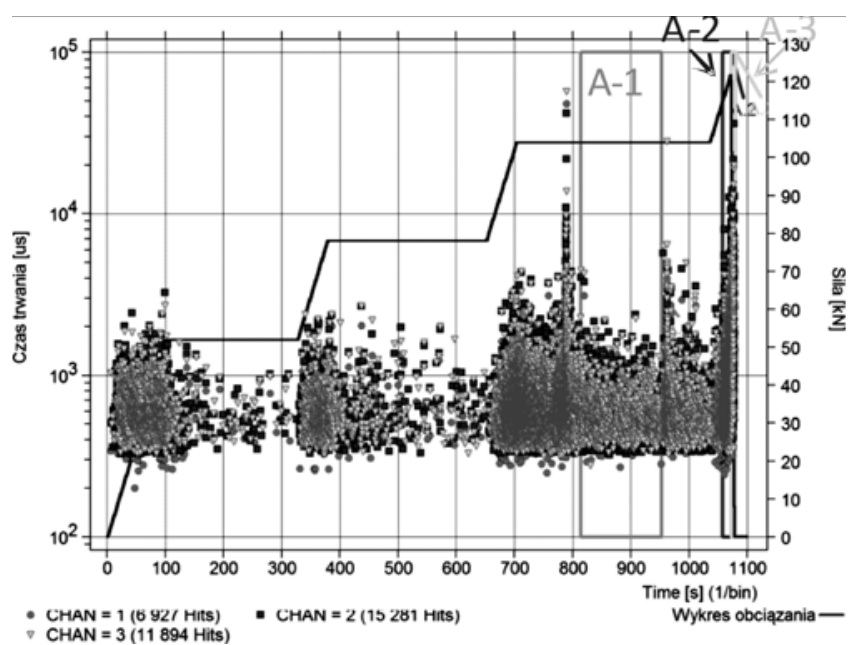

Rys. 5. Czas trwania sygnałów oraz siła w funkcji czasu z naniesionymi charakterystycznymi obszarami

Fig. 5. Duration of $A E$ signals and load as a function of time with selected areas 


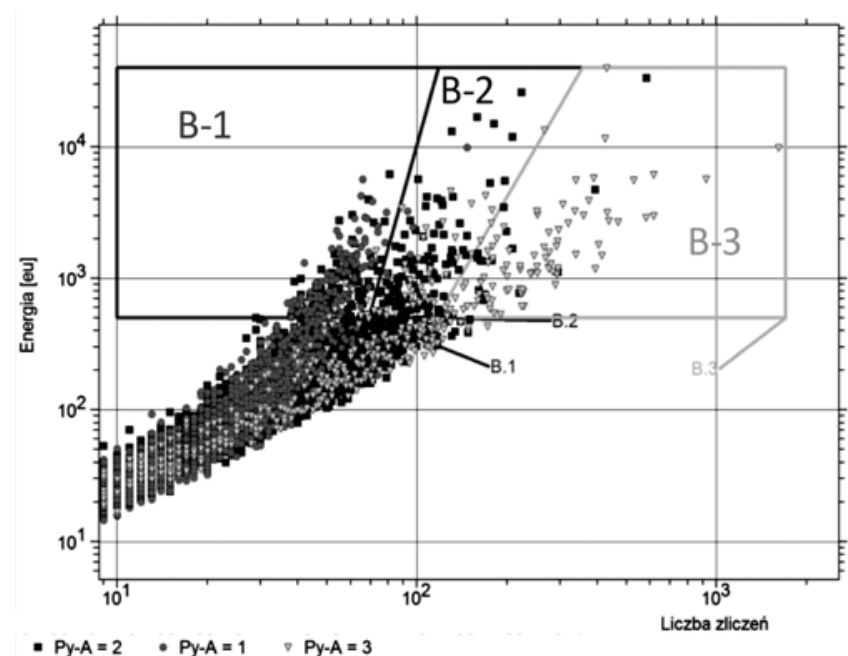

Rys. 6. Wartości energii sygnałów AE oraz liczby zliczeń powyżej progu dyskryminacji dla obszarów wyselekcjonowanych na rysunku 5 Fig. 6. Energy of AE signals as a function of counts for selected areas from Fig. 5.

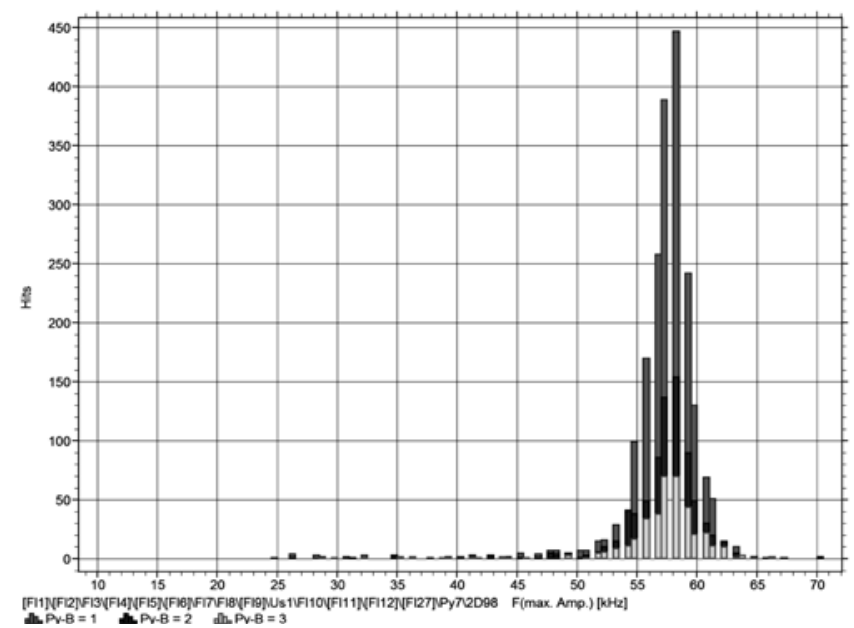

Rys. 7. Rozkład częstotliwości sygnałów $A E$

Fig. 7. Frequency distribution of AE signals

W tym celu wyznaczono trzy charakterystyczne obszary B-1, B-2 i B-3 pokazane na rysunku 6.

Analiza parametryczna wyselekcjonowanych sygnałów wykazała, że częstotliwości sygnałów akustycznych generowanych $w$ procesie obciążania próbek betonowych mieszczą się w zakresie $50 \div 65 \mathrm{kHz}$. Histogram przedstawiający rozkład częstotliwości rejestrowanych sygnałów pokazano na rysunku 7.

W toku dalszej analizy skupiono się na porównaniu wytypowanych grup sygnałów. Do tego celu użyto współczynnika RA, jakim jest stosunek czasu narastania do amplitudy sygnału w funkcji częstotliwości. Współczynnik ten pozwala porównać sygnały o różnych charakterystykach akustycznych związanych z naturą źródła, które te sygnały generuje. Na rysunku 8 zaobserwowano, że największe wartości współczynnika RA obserwuje się dla obszaru B-3, natomiast najmniejsze dla B-1. Najlepsze wyniki separacji uzyskano pomiędzy obszarami B-1 i B-3. Świadczy to o tym, że sygnały w wyselekcjonowanych obszarach mają inne charakterystyki akustyczne. Charakterystyki sygnałów

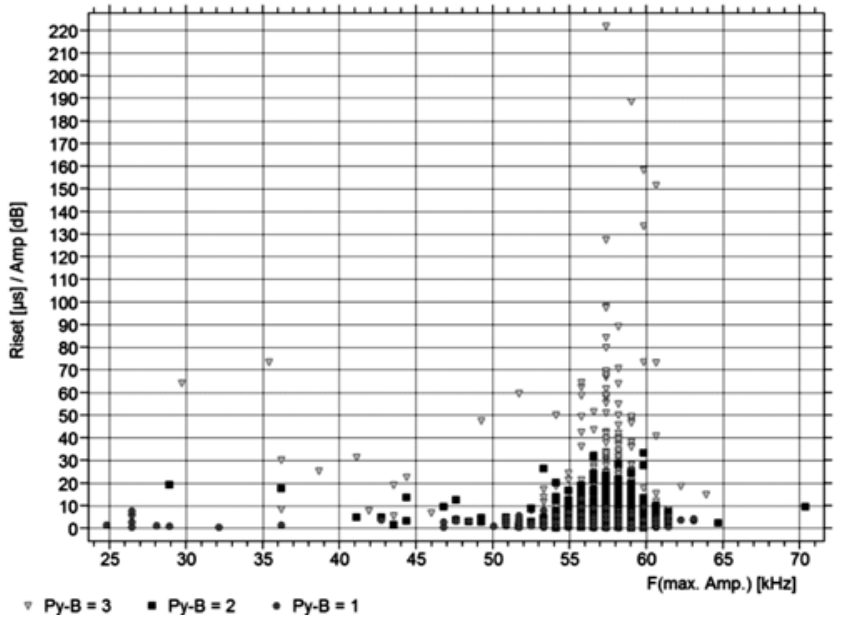

Rys. 8. Wartości parametru RA w funkcji częstotliwości sygnałów

Fig. 8. Value RA parameter as function of frequency

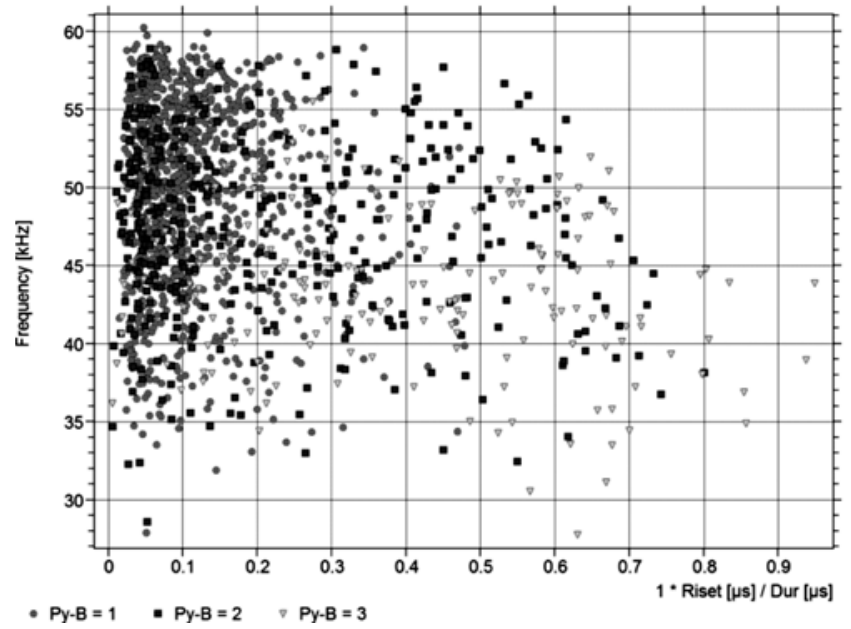

Rys. 9. Średnia częstotliwość sygnałów w funkcji współczynnika RD Fig. 9. Average frequency as function of value RD parameter

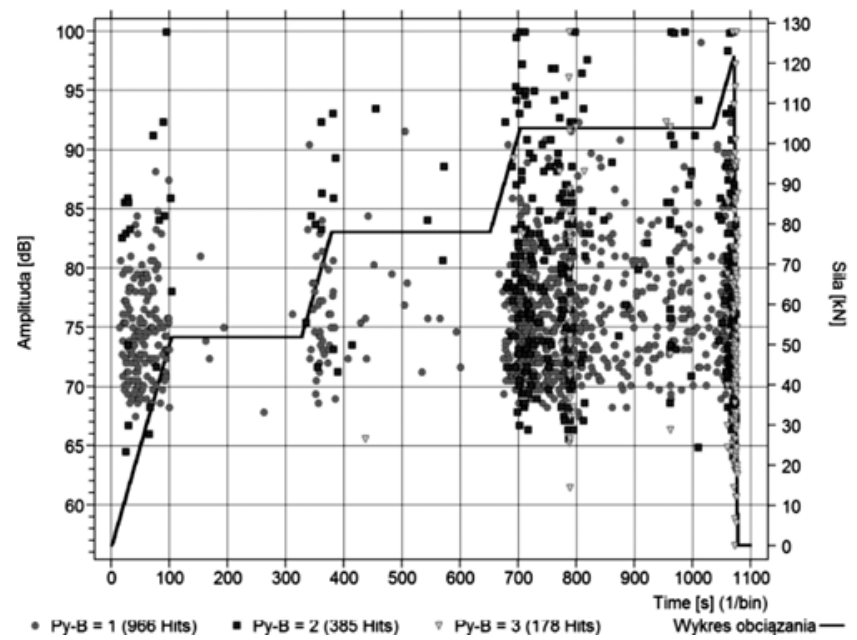

Rys. 10. Amplituda sygnałów oraz siła w funkcji czasu z naniesionymi charakterystycznymi obszarami

Fig. 10. Amplitude of AE signals and load as a function of time for selected areas 
z grupy B-2 noszą cechy sygnałów z grup B-1 i B-3.

Następnie odniesiono średnią częstotliwość sygnałów (iloraz liczby zliczeń powyżej progu dyskryminacji do czasu trwania sygnału), w funkcji współczynnika RD (iloraz czasu narastania do czasu trwania sygnałów), co zobrazowano na rysunku 10 [4]. W wyniku otrzymano dwie grupy sygnałów różniące się charakterystyką. Sygnały z grupy B-3 mają dużo wyższy współczynnik RD w niż sygnały z grupy B-1. Świadczy to o tym, że sygnały B-3 pochodzą głównie od procesów tarcia o siebie popękanych części rdzenia betonu. Sygnały B-1 mają swe źródło w procesach interakcji kruszywa z zaprawą. Do grupy
B-2 należa sygnały, które maja swe źródło w powstawaniu i propagacji mikropęknięć i to właśnie one są charakterystyczne dla procesu niszczenia betonu. $\mathrm{Na}$ te sygnały nakładają się zarówno procesy tworzenia mikropęknięć, jak i procesy tarcia w warstwie kontaktowej kruszywo-ziarno oraz kruszywo-zaprawa.

Sygnały $z$ wytypowanych grup $B-1 \div 3$ naniesiono na wykres amplitudy sygnałów w funkcji czasu (rys. 10). Rozkład sygnałów w odniesieniu do stanu obciążenia koreluje z przypisaniem tych sygnałów do źródeł akustycznych, które generują emisję akustyczną w betonie.

\section{Wnioski}

Badania w statycznej próbie ściskania rdzeni betonowych z równoczesną rejestracją sygnałów akustycznych pozwoliły określić zakres częstotliwości oraz charakterystyczne parametry sygnałów generowanych przez tarcie oraz tworzenie się i rozwój mikropęknięć. Analiza zmian intensywności i aktywności emisji akustycznej pozwoliła na wykrycie momentu, w którym istniejące w materiale mikropęknięcia propagują w materiale i doprowadzają do całkowitego zniszczenia konstrukcji pracującej pod zadanym obciążeniem.

Zebrana charakterystyka akustyczna pozwoli skuteczne monitorować rozwój mikropęknięć podczas badań konstrukcji betonowych.

Korelacja danych emisji akustycznej zebranych podczas badań laboratoryjnych oraz terenowych pozwoli scharakteryzować podatność konstrukcji na rozwój uszkodzeń przy znacznych obciążeniach obiektów wykonanych z betonu.

Stwierdzenie to uzasadnia, że metoda emisji akustycznej bardzo dobrze nadaje się do wykrywania i monitorowania defektów strukturalnych w konstrukcjach betonowych.

\section{Literatura}

[1] EN 1330-9:2009, Non-destructive testing. Terminology. Part 9: Terms used in acoustic emission testing.

[2] EN 15857:2010, Non-destructive testing - Acoustic emission Testing of fibrereinforced polymers - Specific methodology and general evaluation criteria.

[3] I. Malecki, J. Ranachowski: Emisja akustyczna, źródła, metody, zastosowania, Biuro Pascal, Warszawa, 1994.

[4] Masayasu Ohtsu, Toshiro Isoda And Yuichi Tomoda, Acoustic emission techniques standardized for concrete structures $\mathrm{J}$. Acoustic Emission, 25 (2007)
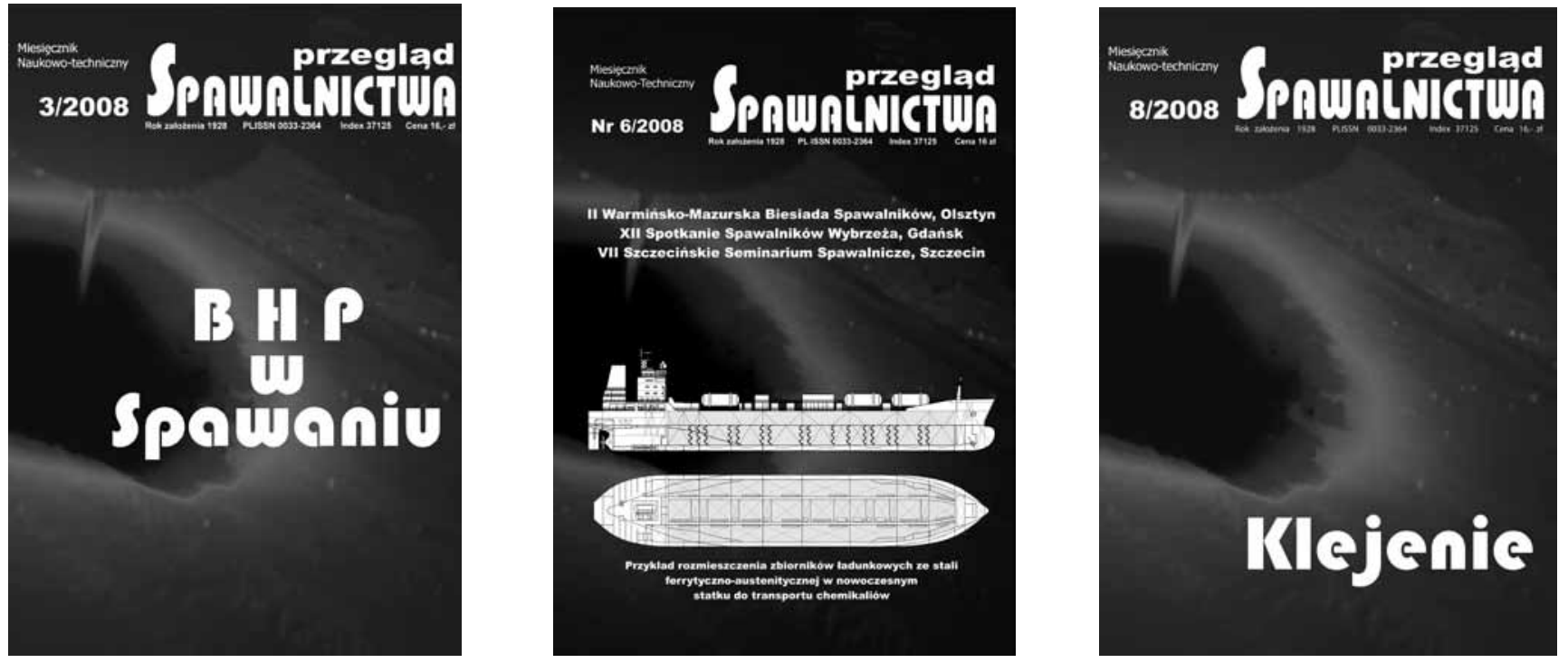